\title{
Professional Satisfaction among B.Sc. Nursing Graduates of an Institute
}

\author{
Mehta RS, ${ }^{1}$ Yadav R' \\ 'B.P. Koirala Institute of Health Sciences, Dharan, Nepal.
}

\begin{abstract}
Introduction: Professional Satisfaction is a measure of valuation judgment of whether the expectations are met from the profession or not. This study was conducted to find out the professional satisfaction among pass-out B.Sc. Nursing graduates from an institute from batches 1996 to 2004.
\end{abstract}

Methods: Descriptive cross-sectional study design was adopted using convenient and snowball sampling technique. Out of 104 graduates, 50 were included in the study. A pre-tested semistructured questionnaire was used by self administration method to collect the information.

Results: Highest satisfaction was with status $36(75 \%)$ and lowest with working condition $27(54 \%)$. The areas with decreasing value of satisfaction were growth and development 36 $(72 \%)$, achievement and recognition $35(70 \%)$, autonomy and challenging work $35(69 \%)$. The majority of the respondents $27(54 \%)$ stated that there is job security in the profession and the opportunity $26(52 \%)$ to help others was the reason for their satisfaction but $28 \%$ said that there is no updating of knowledge and autonomy $15(30 \%)$ in nursing profession.

Conclusions: There is no difference in professional satisfaction of the respondents living in Nepal and abroad. It is seen that though there are many problems and many areas of dissatisfaction in nursing profession the respondents were satisfied to some extent with it and the reason for brain drain among B.Sc. Nursing graduates were their personal interest.

Keywords: graduate; nursing; professional; satisfaction.

\section{INTRODUCTION}

Nursing encompasses autonomous and collaborative care of individuals of all ages, families, groups, and communities, sick or well in all setting. The level of job satisfaction among care workers is positively correlated with client satisfaction. ${ }^{1}$ Similarly, job satisfaction and intention to turnover among care workers have been suggested as important factors determining the quality of services. ${ }^{2}$ Job satisfaction is a strong and significant predictor of worker's intention to leave the job. ${ }^{3}$ Similar findings were also reported in many studies. ${ }^{4-10}$

The objectives of this study was to assess the professional satisfaction among pass-out B.Sc. Nursing graduates of BPKIHS from 1996 to 2004 batch, to compare the professional satisfaction of pass-out B.Sc. Nursing graduates working in Nepal and abroad and to find out the association between professional satisfaction and selected demographic variables.

\section{METHODS}

A descriptive cross sectional research design was used to conduct the study. The research was conducted among pass-out B.Sc. Nursing graduates from BPKIHS (Bishweshwor Prasad Koirala Institute of Health Sciences) from 1996 to 2004 batch living in Nepal and

Correspondence: Dr. Ram Sharan Mehta, Medical-Surgical Nursing Department, B.P. Koirala Institute of Health Sciences, Dharan, Nepal. ramsharanmehta@hotmail.com, Phone: 9842040537. 
abroad and related to nursing profession. A convenient and snowball sampling technique was used to collect the data. Data collection period was from $10^{\text {th }}$ January to $10^{\text {th }}$ June 2009. Fifty subjects were included in the study. A self prepared semi structured pre-tested questionnaire was used for data collection. A list of pass-out B.Sc. Nursing graduates was obtained from Academic Section and corresponding address collected from college of nursing, available friends and relatives. For the pass-out students who were in BPKIHS questionnaire was given directly. Postal, visiting, e-mailing was applied for those in eastern region of Nepal and Kathmandu and e-mailing was done for those working abroad for data collection. The collected data were analyzed using SPSS-15 software package. Ethical approval was taken.

Likert scale was used for rating the satisfaction in different areas. It consists of positive and negative items. Positive items were rated as strongly disagree to strongly agree and the scoring was given accordingly (1, 2, 3, 4 and 5). Reverse scoring was given for negative items i.e. strongly disagree to strongly agree and scoring varied as 5, 4, 3, 2 and 1. Negative items included number 6, 21, 27, 28 and 29 and rest all was positive. Maximum obtainable score was 190. Different items were included to assess the professional satisfaction in each area. Obtained scoring (overall and in specific areas) were converted into percentages and interpreted by using median percentage and inter-quartile range.

\section{RESULTS}

Half of the respondents were of age group 22-25 years. Females were 44 (88\%). Hindus were 49 (98\%) and 25 (50\%) were Brahmin and Chettri, 15 (30\%) were Newar. Married were 28 (56\%), out of which 29 (58\%) were living in Nepal and rest abroad (USA, Bangladesh, South Korea, Ireland, China, India and UK). With regards to work experience, 16 (32\%) had 1-2 yrs of experience and $15(30 \%)$ had $>3$ yrs experience. With regards to qualification 35 (70\%) had not done any further study after finishing bachelor. M. Sc. Nursing was done by 7 $(14 \%)$ and $6(12 \%)$ had done Masters in other nursing related fields.
Majority of the respondents 22 (44\%) were working at the post of Nursing Instructor / Officer / Tutor / Sister and $9(18 \%)$ are at Assistant Lecturer / Researcher. Among the ones living in Nepal most of them (75.9\%) were at officer level post and the rest were at the post higher than officer level. Among the ones living abroad majority $(57.1 \%)$ were nursing students and $33.4 \%$ were working as Staff Nurse.

Majority of the respondents (56\%) said that nursing is a noble profession because of its caring nature and dedication to make a difference in others life (10\%). Thirty percent of the respondents did not answer to this question and $2(4 \%)$ of the respondents said that there is nothing to quote noble for nursing. In their view it is as respected as other professions.

The majority of the respondents (36\%) said that there is lack of autonomy and self sustaining practices in this profession and $16(36 \%)$ mentioned that there is no updating of knowledge and skills. Most of them 10 $(20 \%)$ quoted that there is a social stigma that nurses are assistant to the doctors and ego problems of seniors which is also a problem of this profession. The majority of the respondents 27 (54\%) said job security and 26 $(52 \%)$ said opportunity to help as the major reason for their satisfaction with nursing profession.

Few respondents 10 (20\%) said that there is less reward and it is overshadowed by medical profession and 9 $(18 \%)$ also said that there is social stigma attached with this profession which is the reason for their dissatisfaction with nursing profession. The majority of the respondents $12(24 \%)$ said that one should respect and accept the profession and $8(16 \%)$ said that the pass-out graduates should aspire for higher studies as early as possible in order to improve professional satisfaction among pass-out B.Sc. Nursing graduates from BPKIHS.

The majority of the respondents 22 (44\%) said that there should be adequate supervision and guidance especially in clinical posting and $9(18 \%)$ said that updated information should be given by nursing faculties in their related departments in order to improve nursing training in BPKIHS. 
Mehta et al. Professional Satisfaction among pass-out B.Sc. Nursing Graduates ofHimmelfarb J. Hemodialysis complications...

Table 1. Association between Percentage Satisfaction in Various Components of Profession and Residence.

\begin{tabular}{|c|c|c|c|c|}
\hline \multirow{2}{*}{ S.N. } & \multirow{2}{*}{ Item/ Particulars } & \multicolumn{2}{|c|}{$\begin{array}{l}\text { Median percentage of Professional Satisfaction } \\
\text { (IQR) }\end{array}$} & \multirow{2}{*}{$\mathrm{p}$-value } \\
\hline & & $\begin{array}{l}\text { Nepal } \\
n=29\end{array}$ & $\begin{array}{l}\text { Abroad } \\
\mathrm{n}=21\end{array}$ & \\
\hline 1 & Achievement & $72(60-82)$ & $68(60-76)$ & 0.721 \\
\hline 2 & Recognition and accomplishment & $70(60-80)$ & $70(62.5-80)$ & 0.532 \\
\hline 3 & Autonomy and Challenging work & $71(63-77)$ & $63(55.5-77)$ & 0.309 \\
\hline 4 & Growth and development & $72(60-88)$ & $72(60-90)$ & 0.906 \\
\hline 5 & Salary & $70(60-70)$ & $60(60-75)$ & 0.441 \\
\hline 6 & Interpersonal relationship & $72(64-80)$ & $76(60-80)$ & 0.813 \\
\hline 7 & Working condition & $52(40-64)$ & $64(48-78)$ & 0.068 \\
\hline 8 & Status/Security/Respect & $75(65-85)$ & $70(57.5-77.5)$ & 0.259 \\
\hline 9 & Supervision & $60(50-80)$ & $80(40-80)$ & 0.876 \\
\hline
\end{tabular}

Mann Whitney U Test Key: S = Significant

Table 2. Association between Professional Satisfaction and Selected Independent Variables $(\mathbf{n}=50)$.

\begin{tabular}{|c|c|c|c|c|}
\hline S.N. & Characteristics & Categories & Median percentage of satisfaction (IQR) & p-value \\
\hline 1 & Age & $\begin{array}{l}\leq 25 \text { years } \\
>25 \text { years }\end{array}$ & $\begin{array}{l}65(58-71) \\
72(66-77.5)\end{array}$ & 0.039 \\
\hline 2 & Gender & $\begin{array}{l}\text { Male } \\
\text { Female }\end{array}$ & $\begin{array}{l}74.5(71-77) \\
67.5(58.25-74.75)\end{array}$ & 0.076 \\
\hline 3 & Current residence & $\begin{array}{l}\text { Nepal } \\
\text { Abroad }\end{array}$ & $\begin{array}{l}68(60-75) \\
68(61-76)\end{array}$ & 0.992 \\
\hline 4 & Marital status & $\begin{array}{l}\text { Single } \\
\text { married }\end{array}$ & $\begin{array}{l}66.5(58-72) \\
73(65-77)\end{array}$ & 0.074 \\
\hline 5 & $\begin{array}{l}\text { Duration of } \\
\text { employment }\end{array}$ & $\begin{array}{l}\leq 1 \mathrm{yr} \\
>1 \mathrm{yr}\end{array}$ & $\begin{array}{l}65.5(57.75-77.25) \\
69(64.25-75)\end{array}$ & 0.342 \\
\hline 6 & Living & $\begin{array}{l}\text { Alone } \\
\text { With spouse / } \\
\text { family or others }\end{array}$ & $\begin{array}{l}67.5(58.25-71) \\
68.5(62-75.5)\end{array}$ & 0.341 \\
\hline 7 & Post / designation & $\begin{array}{l}\text { > officer level } \\
\leq \text { officer level }\end{array}$ & $\begin{array}{l}74(65.5-76.5) \\
69(64.25-77)\end{array}$ & 0.764 \\
\hline
\end{tabular}

Mann Whitney U Test

Key: S = Significant

\section{DISCUSSION}

Regarding the attitude of the respondents, only six percent of all the respondents stated that they regret for choosing nursing profession whereas $6.8 \%$ of respondents living in Nepal and $4.8 \%$ of ones living abroad regret for choosing nursing profession. Majority of the respondents (58\%) aimed to become doctor before joining nursing profession and this might be the reason that they regret for joining nursing profession. Only $24(48 \%)$ wanted to continue nursing profession 
and $6(12 \%)$ wanted to switch to other profession, $9(18 \%)$ had still not decided what they are going to do in future. It might be because they wanted to become doctor but joined nursing profession forcefully. Majority of the respondents 28 (56\%) thought they have average status according to them and 14 (42\%) thought they have high status according to their people. None of them stated that they had very low status. So, regarding status they have positive attitude.

The study results showed that the median percentage of satisfaction with achievement, recognition and accomplishment was $35(70 \%)$ and it was almost the same for the ones living in Nepal and abroad showing that there is no difference in satisfaction with achievement, recognition and accomplishment in comparison with residence. It might be because the expectations of the respondents are fulfilled in these areas.

The median percentage of satisfaction with autonomy was found to be $69 \%$ and in Nepal and abroad it was $71 \%$ and $63 \%$ respectively showing that the ones living in Nepal were more satisfied with autonomy that the ones living abroad (Table 1). This might be because the ones living in Nepal are at higher posts than the ones living in abroad and have more autonomy. The result is supported by the study conducted in England which stated that flexibility i.e. autonomy or its absence in working arrangements appear to be a key factor influencing nurse's decision to leave. ${ }^{7}$

Findings revealed that the median percentage of satisfaction with growth and development in nursing profession was $72 \%$ and it was the same for the ones living in Nepal and abroad showing that the satisfaction with growth and development did not differ with the current residence of respondents. It might be because the respondents get opportunity for growth and development not only abroad but also in Nepal.

The study results confirmed that there was a significant relationship between age and professional satisfaction and it showed that the respondents of age more than 25 years were more satisfied (median percentage of satisfaction $=72$ ) than the ones with age less than or equal to 25 years (median percentage of satisfaction $=$
65). The findings of a study conducted in Japan 550 female nursing home care workers in 2005 confirmed results of some prior studies, showing a significant positive relationship between age and overall job satisfaction. $^{2}$

The study results showed that there was no association between professional satisfaction and gender which means that there is no significant difference in the professional satisfaction of male and female. But it was observed that male (74.5) had a higher median percentage of satisfaction than female (67.5).

The study showed that there was no association between the professional satisfaction and post or designation but there was an increasing trend in the median percentage of satisfaction among student $(63 \%)$, respondents at the post less than or equal to officer level $(69 \%)$ and more than officer level (74\%) (Table 2). Certainly the ones who are employed are expected to be more satisfied than the ones who are not employed at all i.e. students and when they are employed they thrive for higher post and the ones in higher post are expected to be more satisfied.

Most of the graduates suggested for higher studies as soon as possible (16\%) and to think positively (14\%). They also suggested for improvement in nursing training in BPKIHS. Majority of the respondents (44\%) said that there should be adequate supervision and guidance especially in clinical posting and $14 \%$ said that there should be continue training by nursing faculties in their related departments.

\section{CONCLUSIONS}

This study concludes that there is no difference in professional satisfaction of the respondents living in Nepal and abroad. Satisfaction is dependent upon age but not upon other independent variables like gender, current residence, marital status and designation. This study can be conducted among other levels of nursing personnel's like certificate, bachelor and masters to find out the professional satisfaction, which will give a wider concept of satisfaction associated with nursing profession.

\section{REFERENCES}

1. Treng HM, Ketefian S, Redman RW. Relationship of nurse's assessment of organizational culture, job satisfaction and patient satisfaction with nursing care. Int J Nurs stud. 2001;22:3-14.

2. Watanabe RN. Effect of age on job satisfaction and intention to turnover among female nursing home care workers. Journal of Policy Studies. 2005 Mar;19:75-89.

3. Gleason WP, Mindel CH. A proposed model for predicting job satisfaction among nursing home social workers. J Geronto Soc Work. 1999;32:65-79.

4. Gaur L, Chandler B, Burton B, Kolditz D. Institutional loyalty and job satisfaction among nurse aides in nursing homes. Journal of Aging and Health.1991;3:47-65. 
5. Mason D. Letters: Who's watching nurses? Am J Nurs [Serial online]. 2009 Mar [cited 2009 July 17]. Available from: URL:http://hinari_gw.who.int

6. Burton EC and Burton DT. Job expectations of senior nursing students. J Nurs Adm. 1982;12(3):11-7.

7. Storey C, Cheater F, Ford J, Leese B. Retention of nurses in the primary and community care workforce after the age of 50 years: database analysis and literature review. J Adv Nurs. 2009 Mar;65(8):1596-605.
8. Weisman CS. Recruit from within: hospital nurse retention in the 1980's. J Nurs Adm. 1982;12(5):24-31.

9. Yamashita M. Job satisfaction in Japanese Nurses. J Adv Nurs. 1995; 22(1):158-64.

10. Murrells T, Robinson S, Griffiths P. Job satisfaction trends during nurses' early career. BioMed Central. 2008;(7)7:152-4. 